\title{
Pengaruh Pendidikan Kebencanaan Terhadap Perilaku Kesiapsiagaan Bencana Gempa Bumi Di Mts Muhammadiyah 6 Bayat
}

\author{
Tasha Vima Eka ${ }^{1 *}$, Ayu Wanda Sari ${ }^{1}$, Diah Ayu Permatasari ${ }^{1}$, \\ Febrian Adhira R P1 , Candra Syahrul I ${ }^{1}$ \\ ${ }^{1}$ Program Studi Pendidikan Geografi, Universitas Muhammadiyah Surakarta, Jl. A Yani Pabelan \\ Kartasura, Surakarta 57102, Indonesia \\ Email : *Tashavima280815@gmail.com, Yuansarii4@gmail.com, \\ Diahayupermatasari84@gmail.com, Candrasyahru18@gmail.com, Brianadhira10@yahoo.com, \\ Puspitadewiratih79@yahoo.com
}

Dikirim : 21 Desember 2019

Diterima: 31 Maret 2020

\begin{abstract}
Abstrak : Kabupaten Klaten sebagai salah satu kabupaten di Provinsi Jawa Tengah merupakan daerah rawan terjadi bencana alam seperti gempa bumi, banjir, tanah longsor, kekeringan dan angin puting beliung. Tujuan dari pendidikan mitigasi ini mengajarkan pembelajaran kebencanaan dengan baik dan benar sehingga siswa mampu siap siaga dalam ancaman bencana di lingkungan sekolah. Populasi dalam penelitian ini adalah sebanyak 100 warga sekolah. Warga sekolah tersebut yaitu siswa sejumlah 85 , dan guru sejumlah 15 di MTs Muhammadiyah 6 Bayat, Kabupaten Klaten. Pengambilan sampel menggunakan teknik random sampling dengan metode slovin. Hasil penelitian menunjukkan bahwa siswa Mts Muhammadiyah 6 Bayat masih memiliki pengetahuan yang cukup rendah tentang kesiapsiagaan bencana.
\end{abstract}

Kata kunci: pengaruh pendidikan, kebencanaan, perilaku kesiapsiagaan

Abstract: Klaten Regency as one of the regencies in Central Java Province is prone to natural disasters such as earthquakes, floods, landslides, droughts and tornadoes. The purpose of this mitigation education is to teach disaster learning properly and correctly so that students are able to be prepared for disaster threats in the school environment. The population in this study were 100 school residents. The school residents are 85 students, and 15 teachers in MTs Muhammadiyah 6 Bayat, Klaten Regency. Sampling using a random sampling technique with Slovin method. The results showed that the students of Mts Muhammadiyah 6 Bayat still had quite low knowledge about disaster preparedness.

Keywords: the influence of education, disaster, preparedness behavior

\section{Pendahuluan}

Kabupaten Klaten sebagai salah satu kabupaten di Provinsi Jawa Tengah merupakan daerah rawan terjadi bencana alam seperti gempa bumi, banjir, tanah longsor, kekeringan dan angin putting beliung. Hal ini dapat terjadi karena letaknya yang berada di wilayah Jawa Tengah bagian selatan dekat dengan daerah pertemuan lempeng dan merupakan daerah dataran rendah, sehingga rawan terjadi gempa bumi dan banjir jika intensitas curah hujan begitu tinggi. Menyadari adanya risiko bencana, penting ditumbuhkan sikap kesiapsiagaan meliputi kesadaran dan pembudayaan pengurangan risiko bencana baik dimasyarakat maupun sekolah.

Pengurangan risiko bencana dapat dilakukan melalui pendidikan Kebencanaan dalam sekolah maupun pmbentukan Sekolah Siaga Bencana (SSB). Pengupayaan kesiapsiagaan bencana di sekolah merupakan upaya dan tanggung jawab bersama dari warga sekolah dan para pemangku kepentingan sekolah. Kesiapsiagaan didefinisikai sebagai tindakan atauaktivitas yang dilakukan sebelum suatu bencana terjadi. Kesiapsiagaan menurut (Gregg 2004), bertujuan untuk meminimalkan efek samping bahaya melalui tindakan pencegahan yang 
efektif, tepat waktu, memadai,efesiensi untuk tindakan tanggap darurat dan bantuan saat bencana.

Tujuan dari pembelajaran pendidikan mitigasi bencana tidak hanya sebagai trasfer ilmu oleh guru terhadap siswa, melainkan perubahan pola pikir siswa tersebut. Dengan adanya pembelajaran pendidikan mitigasi bencana tersebut diharapkan guru mampu mengajarkan pembelajaran kebencanaan dengan baik dan benar sehingga siswa mampu bersiap siaga dalam ancaman bencana di lingkungan sekolah. Pentingnya pendidikan kebencanaan berpengaruh besar terhadap pengetahuan siswa yang berada di tingkat sekolah menengah pertama seperti MTs Muhammadiyah 6 Bayat ini sehingga anak didik mampu mengetahui bagaimana harus bersikap dan bertindak pada saat terjadi bencana.

Pada kesempatan ini penelitian dilakukan di salah satu sekolah Kabupaten Klaten. Sekolah tersebut yaitu MTs Muhammadiyah 6 Bayat. Berdasarkan latar belakang ini, maka penelitian terhadap pendidikan kebencanaan gempa bumi di MTs Muhammadiyah 6 Bayat melalalui pembelajaran pendidikan kebencanaan gempa bumi yang telah dilaksanakan di sekolah tersebut. Penelitian ini guna mengetahui bagaimana respon siswa dan guru dalam perilaku kesiapsiagaan bencana gempa bumi dibuat lembar kerja kuisioner yang telah tersusun. Sehingga dapat disimpulkan untuk penelitian ini yang mencakup pendidikan kebencanaan dan pengetahuan siswa dan guru dalam perilaku kesiapsiagaan bencana gempa bumi.

\section{Metode Penelitian}

Metode penelitian ini menggunakan analisis deskripsi kuantitatif, dengan menyajikan data melalui diagram. Penelitian ini melibatkan 4 program di Mts Muhammadiyah 6 Bayat. Populasi dalam penelitian ini adalah sebanyak 100 warga sekolah. Warga sekolah tersebut yaitu siswa sejumlah 85, dan guru sejumlah 15 di MTs Muhammadiyah 6 Bayat, Kabupaten Klaten. Pengambilan sampel menggunakan teknik random sampling dengan metode slovin.

\section{Pengumpulan data}

Pengumpulan data yang diambil dengan membagikan kuisioner dan observasi dengan metode terbuka, jawaban sudah ditentukan terlebih dahulu dan responden diberikan alternative jawaban ya atau tidak dan pilihan ganda. Kuesioner merupakan teknik pengumpulan data dengan cara mengirimkan suatu daftar pertanyaan kepada responden untuk di isi (Sukandarumidi, 2002). Observasi merupakan suatu proses yang tersusun dari berbagai proses biologis dan psikologis, Teknik ini digunakan untuk mendapatkan data primer dengan datang langsung ke lapangan untuk pengamatan langsung. Populasi yang diambil dalam penelitian ini adalah Mts Muhammadiyah 6 Bayat yang melibatkan guru dan siswa.

\section{Analisis data}

Analisis deskriptif adalah statistik yang digunakan untuk menganalisis data dengan cara mendeskripsikan atau menggambarkan data yang telah terkumpul sebagaimana adanya tanpa bermaksud membuat kesimpulan yang berlaku untuk umum atau generalisasi (Sugiyono, 2012). Analisis data yang dilakukan oleh peniliti dalam penelitian ini melalui grafik yang merupakan hasil dari pengambilan data di lapangan.

Data yang diperoleh dari lapangan di kelompokkan dan disusun kemudian di analisis. Teknik analisisi yang digunakan adalah deskripsi kualitatif, dan deskripsi kuantitatif adalah menjelaskan sesuai fenomena yang ada di sekolah tersebut.

\section{Hasil Penelitian}




\section{Variabel Bebas}

Variabel penelitin ini meliputi pendidikan kebencanaan. Data variabel tersebut diperoleh peneliti dari hasil kuisioner yang digunakan merupakan gabungan dari beberapa sumber yang telah di validasi.

\section{a. Tingkat Pendidikan Kebencanaan}

\section{PENDIDIKAN SISWA REGULER}

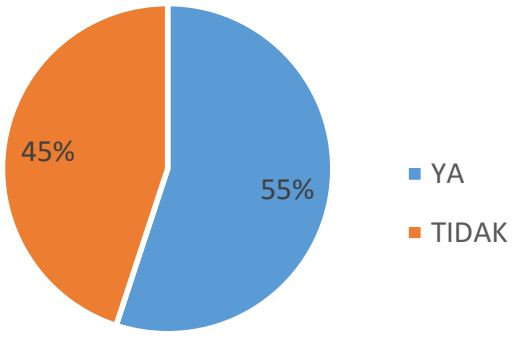

Gambar 1. Diagram Tingkat Pendidikan Kebencanaan Siswa Reguler (sumber: penelitian 2019)

Gambar tersebut merupakan diagram Pendidikan Siswa Reguler di MTs Muhammadiyah 6 Bayat. Dari data diatas dapat dilihat bahwa pendidikan siswa reguler dalam materi kebencanaan menunjukan angka 55\% sebagai jawaban "Ya" dan 45\% sebagai jawaban "Tidak"

\section{PENDIDIKAN SISWA PROGRAM KHUSUS}

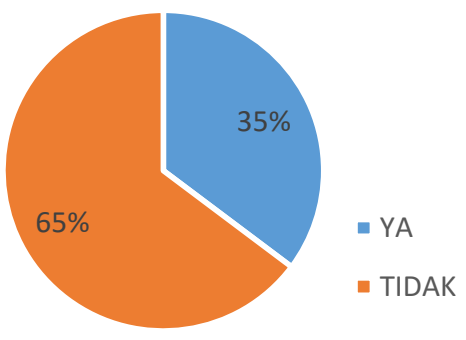

Gambar 2. Diagram Tingkat Pendidikan Kebencanaan Siswa Program Khusus (sumber: penelitian 2019)

Gambar tersebut merupakan diagram Pendidikan Siswa Program Khusus di MTs Muhammadiyah 6 Bayat. Dari data diatas dapat dilihat bahwa pendidikan siswa dalam materi kebencanaan menunjukan angka 35\% sebagai jawaban "Ya" dan 65\% sebagai jawaban "Tidak". 


\section{PENDIDIKAN GURU REGULER}

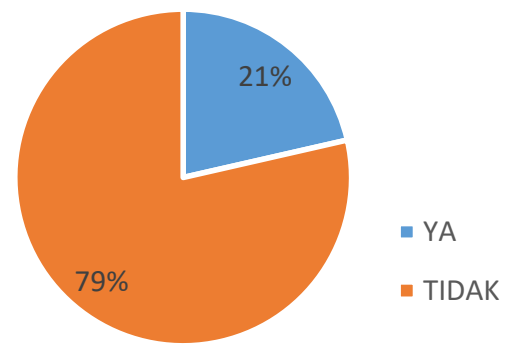

Gambar 3. Diagram Tingkat Pendidikan Kebencanaan Guru Reguler (sumber: penelitian 2019)

Gambar tersebut merupakan diagram Pendidikan Guru Reguler di MTs Muhammadiyah 6 Bayat. Dari data diatas dapat dilihat bahwa pendidikan guru reguler dalam materi kebencanaan menunjukan angka 21\% sebagai jawaban "Ya" dan 79\% sebagai jawaban "Tidak".

\section{PENDIDIKAN GURU PROGRAM KHUSUS}

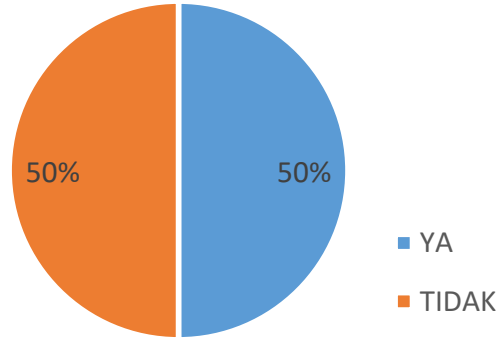

Gambar 4. Diagram Tingkat Pendidikan Kebencanaan Guru Program Khusus (sumber: penelitian 2019)

Gambar tersebut merupakan diagram Pendidikan Guru Program Khusus di MTs Muhammadiyah 6 Bayat. Dari data diatas dapat dilihat bahwa pendidikan guru dalam materi kebencanaan menunjukan angka 50\% sebagai jawaban "Ya" dan 50\% sebagai jawaban "Tidak".

\section{Variabel Terikat}

Variabel penelitin ini meliputi perilaku kesiapsiagaan bencana oleh siswa dan guru. Data variabel tersebut diperoleh peneliti dari hasil kuisioner yang digunakan merupakan gabungan dari beberapa sumber yang telah di validasi

Setelah dilakukan pengambilan data dengan kuesioner diperoleh hasil sebagai berikut:

b. Tingkat Pengetahuan Pengalaman Gempa 


\section{PENGALAMAN SISWA REGULER}

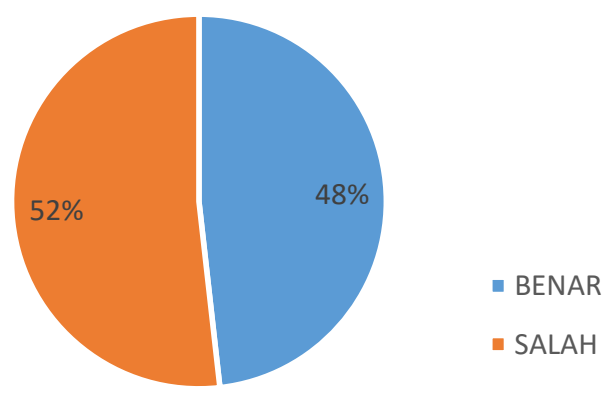

Gambar 5. Diagram Tingkat Pengetahuan Pengalaman Gempa Siswa Reguler (sumber: penelitian 2019)

Gambar tersebut merupakan grafik Pengalaman Siswa Reguler di MTs Muhammadiyah 6 Bayat tentang Bencana Gempabumi. Dari data diatas dapat dilihat bahwa pengalaman siswa reguler dalam tindakan sesuai pengalaman menunjukan angka $48 \%$ sebagai jawaban yang benar dan $52 \%$ sebagai jawaban salah.

\section{PENGALAMANSISWA PROGRAM KHUSUS}

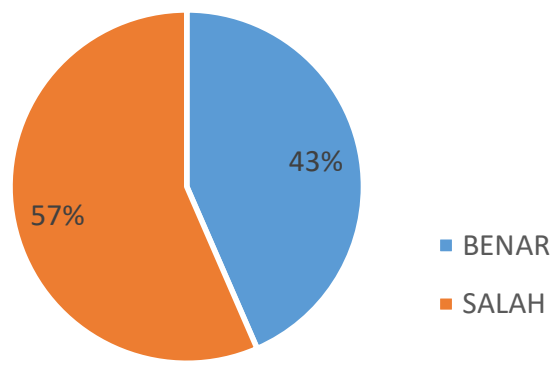

Gambar 6. Diagram Tingkat Pengetahuan Pengalaman Gempa Siswa Program Khusus (sumber: penelitian 2019)

Gambar tersebut merupakan diagram Pengalaman Siswa Program Khusus di MTs Muhammadiyah 6 Bayat tentang Bencana Gempabumi. Dari data diatas dapat dilihat bahwa pengalaman siswa dalam melakukan tindakan sesuai pengalaman menunjukan angka $43 \%$ sebagai jawaban yang benar dan 57\% sebagai jawaban salah.

Jadi dapat dilihat pada kedua diagram tersebut untuk tindakan yang benar sesuai pengalaman gempabumi yang pernah terjadi Siswa Reguler lebih mengerti bagaimana yang perlu dilakukan dengan tindakan yang benar apabila terjadi ancaman gempabumi. Namun, dari kedua grafik tersebut terlihat bahwa angka kesalahan siswa dalam menjawab lebih tinggi dari yang benar. Maka, dapat disimpulkan bahwa melalui pengalaman yang pernah terjadi bencana gempa bumi siswa belum mampu dengan baik melakukan tindakan-tindakan yang perlu dilakukan apabila terjadi ancaman gempabumi yang terulang. 


\section{PENGALAMAN GURU REGULER}

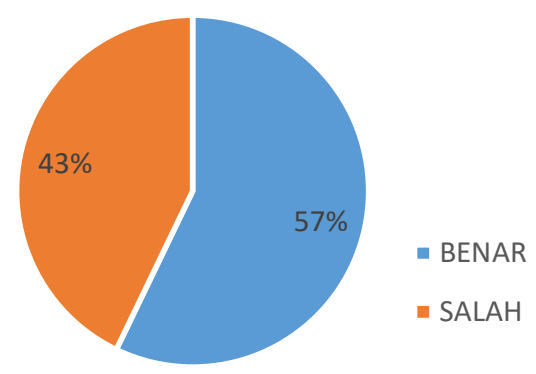

Gambar 7. Diagram Tingkat Pengetahuan Pengalaman Gempa Guru Reguler (sumber: penelitian 2019)

Gambar tersebut merupakan grafik Pengalaman Guru Reguler di MTs Muhammadiyah 6 Bayat tentang Bencana Gempabumi. Dari data diatas dapat dilihat bahwa pengalaman guru reguler dalam tindakan sesuai pengalaman menunjukan angka 57\% sebagai jawaban yang benar dan $43 \%$ sebagai jawaban salah.

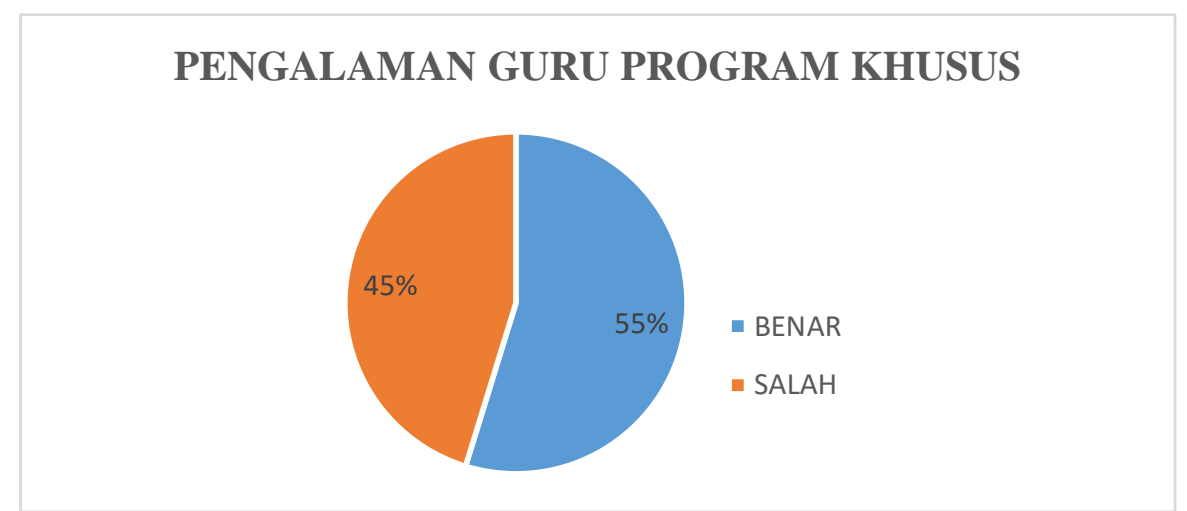

Gambar 8. Diagram Tingkat Pengetahuan Pengalaman Gempa Guru Program Khusus (sumber: penelitian 2019)

Gambar tersebut merupakan diagram Pengalaman Guru Program Khusus di MTs Muhammadiyah 6 Bayat tentang Bencana Gempabumi. Dari data diatas dapat dilihat bahwa guru dalam melakukan tindakan sesuai pengalaman menunjukan angka $45 \%$ sebagai jawaban yang benar dan 55\% sebagai jawaban salah.

Jadi dapat dilihat pada kedua diagram tersebut untuk tindakan yang benar sesuai pengalaman gempabumi yang pernah terjadi Guru Reguler lebih mengerti bagaimana yang perlu dilakukan dengan tindakan yang benar apabila terjadi ancaman gempabumi dengan presentase 57\% sedangkan Guru Program Khusus 55\%. Namun, dari kedua grafik tersebut terlihat bahwa selisih presentase kesalahan guru dalam menjawab lebih tinggi dari yang benar hanya $2 \%$. Maka, dapat disimpulkan bahwa melalui pengalaman yang pernah terjadi bencana gempa bumi guru mampu dengan baik melakukan tindakan-tindakan yang perlu dilakukan apabila terjadi ancaman gempabumi yang terulang kembali.

3. Pengetahuan, Sikap dan Kesiapsiagaan 


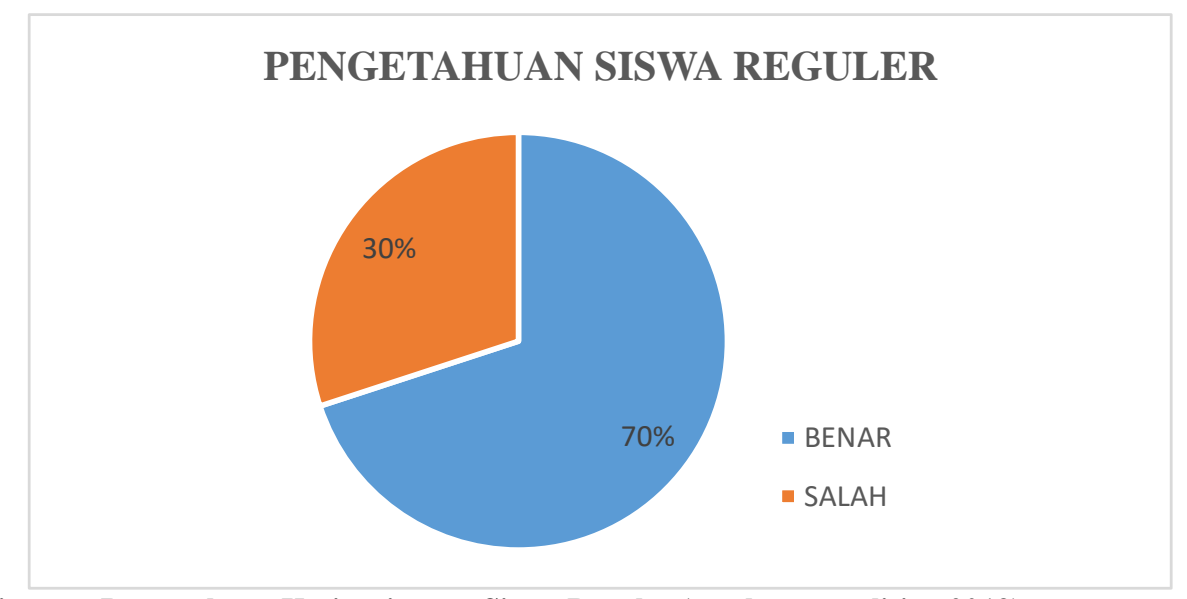

Gambar 9. Diagram Pengetahuan Kesiapsiagaan Siswa Reguler (sumber: penelitian 2019)

Gambar tersebut merupakan diagram Pengetahuan Siswa Reguler di MTs Muhammadiyah 6 Bayat tentang Bencana Gempabumi. Dari data diatas dapat dilihat bahwa pengetahuan siswa reguler mengenai bancana gempabumi menunjukan angka $70 \%$ sebagai jawaban yang benar dan $30 \%$ sebagai jawaban salah.

\section{PENGETAHUANSISWA PROGRAM KHUSUS}

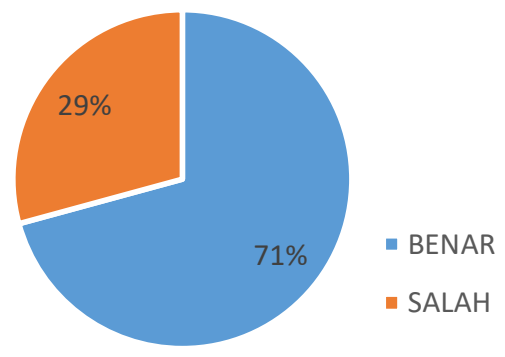

Gambar 10. Diagram Pengetahuan Kesiapsiagaan Siswa Program Khusus (sumber: penelitian 2019)

Gambar tersebut merupakan diagram Pengetahuan Siswa Program Khusus di MTs Muhammadiyah 6 Bayat tentang Bencana Gempabumi. Dari data diatas dapat dilihat bahwa pengetahuan siswa program khusus mengenai bancana gempabumi menunjukan angka $71 \%$ sebagai jawaban yang benar dan $29 \%$ sebagai jawaban salah.

Jadi dapat dilihat pada kedua diagram tersebut untuk pengetahuan bencana gempabumi baik yang pernah terjadi siswa program khusus lebih mengerti bagaimana yang perlu dilakukan dengan tindakan, sikap dan kesiapsiagaan yang benar apabila terjadi ancaman gempabumi dengan presentase $71 \%$ sedangkan siswa reguler $70 \%$. Namun, dari kedua grafik tersebut terlihat bahwa selisih presentase kesalahan siswa dalam menjawab lebih tinggi dari yang benar hanya $1 \%$. Maka, dapat disimpulkan bahwa melalui pengetahuan dari sikap dan kesiapsiagaan terhadap bencana gempabumi, siswa mampu dengan baik melakukan tindakan-tindakan dan sikap yang sesuai untuk dilakukan apabila terjadi ancaman gempabumi yang terulang kembali. 


\section{PENGETAHUAN GURU REGULER}

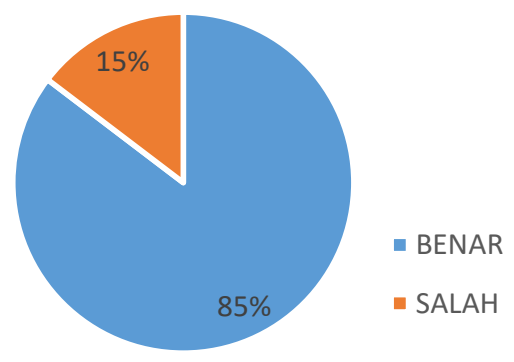

Gambar 11. Diagram Pengetahuan Kesiapsiagaan Guru Reguler (sumber: penelitian 2019)

Gambar tersebut merupakan diagram Pengetahuan Guru Reguler di MTs Muhammadiyah 6 Bayat tentang Bencana Gempabumi. Dari data diatas dapat dilihat bahwa pengetahuan guru reguler mengenai bancana gempabumi menunjukan angka $85 \%$ sebagai jawaban yang benar dan $15 \%$ sebagai jawaban salah.

\section{PENGETAHUAN GURU PROGRAM KHUSUS}

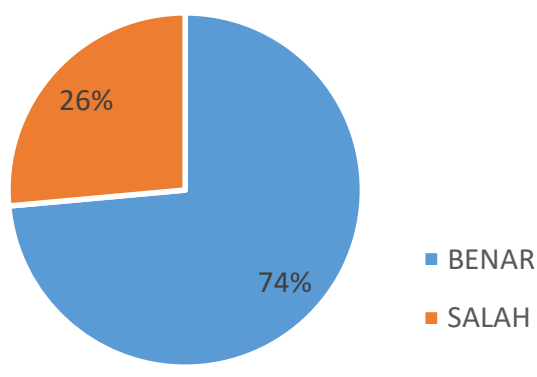

Gambar 12. Diagram Pengetahuan Kesiapsiagaan Guru Program Khusus (sumber: penelitian 2019)

Gambar tersebut merupakan diagram Pengetahuan Guru Program Khusus di MTs Muhammadiyah 6 Bayat tentang Bencana Gempabumi. Dari data diatas dapat dilihat bahwa pengetahuan guru program khusus mengenai bancana gempabumi menunjukan angka $74 \%$ sebagai jawaban yang benar dan $26 \%$ sebagai jawaban salah.

Jadi dapat dilihat pada kedua diagram tersebut untuk pengetahuan bencana gempabumi baik yang pernah terjadi guru rewguler lebih mengerti bagaimana yang perlu dilakukan dengan tindakan, sikap dan kesiapsiagaan yang benar apabila terjadi ancaman gempabumi dengan presentase $85 \%$ sedangkan guru program khusus $74 \%$. Namun, dari kedua grafik tersebut terlihat bahwa selisih presentase kesalahan guru dalam menjawab lebih tinggi dari yang benar sebanyak 11\%. Maka, dapat disimpulkan bahwa melalui pengetahuan dari sikap dan kesiapsiagaan terhadap bencana gempabumi, guru mampu dengan baik melakukan tindakantindakan dan sikap yang sesuai untuk dilakukan apabila terjadi ancaman gempabumi yang terulang kembali.

\section{Pembahasan}

Melihat hasil analisis data dari test dalam bentuk kuisioner/angket yang diberikan kepada guru dan siswa di MTs Muhammadiyah 6 Bayat terdapat perbedaan skor yang tipis disetiap kategori soal yang telah disajikan dalam angka diagram presentasi tersebut. Dapat dijelaskan bahwa terdapat pengaruh pendidikan bencana terhadap kesiapsiagaan bencana gempa bumi pada guru dan siswa saat sebelum mendapat pendidikan bencana dan sesudah mendapat pendidikan bencana baik disekolah maupun kegiatan workshop atau seminar kebencanaan yang telah dilakukan guru. Namun, sebagai siswa MTs tentu memiliki 
pengetahuan tentang kebencanaan dan kesiapsiagaan bencana gempa bumi yang cukup rendah. Pengetahuan tersebut dapat siswa terima tidak hanya dari pendidikan melalui pembelajaran disekolah tetapi juga dilingkungan sekitar dan berita televisi maupun media sosial. Namun, siswa hanya mengerti beberapa informasi dan masih belum begitu faham dengan jelas disetiap informasi kejadian bencana gempa bumi.

Faktor usia merupakan variabel dari individu, yang pada dasarnya semakin bertambah usia seseorang akan semakin bertambah kedewasaannya dan semakin banyak menyerap informasi yang akan mempengaruhi produktivitasnya, dalam hal ini perilaku kesiapsiagaan dalam menghadapi bencana (Gibson, et.al. (1987). Kerentanan siswa yang tergolong sebagai anak-anak tersebut terhadap bencana gempa bumi dipicu oleh faktor keterbatasan pemahaman mengenai risiko-risiko di sekeliling mereka, yang dapat mengakibatkan tidak adanya kesiapsiagaan dalam menghadapi bencana. Melalui pelaksanaan pendidikan bencana yang tidak terlaksana dengan rutin dalam seminggu merupakan salah satu faktor yang menjadikan subjek yang masih dalam perkembangan anak-anak menjadi tidak terbiasa, bahkan telah lupa dengan apa yang pernah diinformasikan dalam pertemuan sebelumnya di tiap kelas. Terkadang subjek tidak ingat dalam berperilaku kesiapsiagaan menghadapi bencana gempa bumi yang pernah diajarkan dan apabila siswa belum pernah mengikuti kegiatan penginformasian kesiapsiagaan akan bencana yang dilakukan pihak sekolah melalui simulasi secara langsung di lingkungan sekolah tersebut.

Berbeda dengan siswa, sebagai seorang guru yang memiliki wawasan luas mampu mendapatkan informasi yang cukup luas dari setiap acara/kegiatan seminar maupun workshop tentu mampu membuat guru tersebut lebih memahami informasi pendidikan kebencanaan gempa bumi dan kesiapsiagaanya. Pemahaman pendidikan kebencanaan gempa bumi dari setiap siswa dapat dipengaruhi pula diri pendidikan yang guru dapatkan dan telah diajarkan kepada mereka.
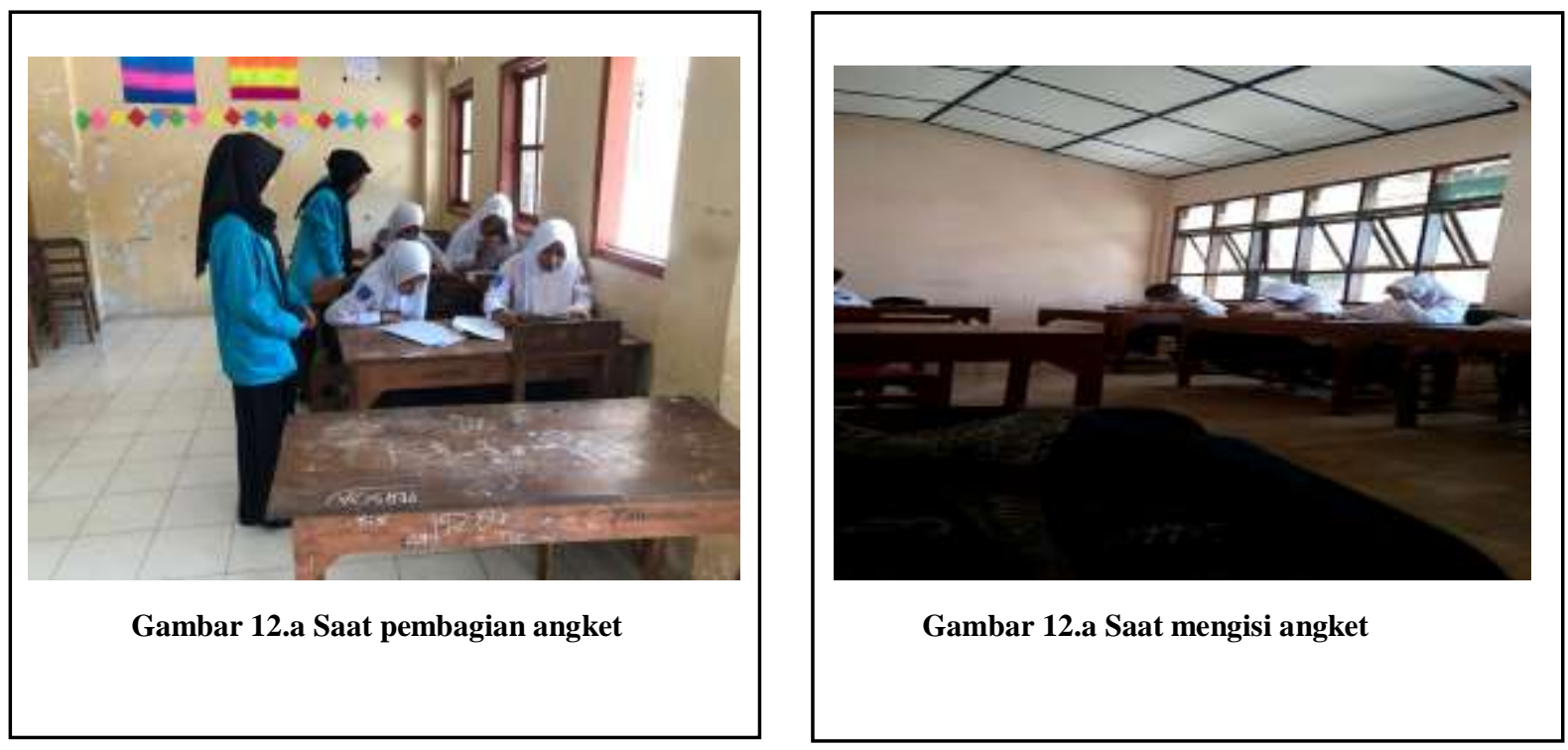

\section{Kesimpulan}

Berdasarkan analisis yang dilakukan, dapat disimpulkan bahwa guru sudah menerapkan pendidikan kesiapsiagaan saat gempa bumi terjadi, Namun masih cukup rendah pendidikan kesiapsiagaan yang siswa terima karena belum terlaksana dengan rutin dalam pembelajaran hanya diterapkan seminggu sekali. Berbeda dengan guru yang sudah memiliki pengetahuan 
tentang kesiapsiagaan yang lebih luas dari setiap acara seminar maupun workshop. Pengetahuan siswa tentang kesiapsiagaan dipengaruhi oleh tingkat pengetahuan guru dan pendidikan yang telah diajarkan.

\section{Ucapan Terimakasih}

Peneliti mengucapkan banyak terimakasih kepada Program Studi Pendidikan Geografi, Fakultas Keguruan dan Ilmu Pendidikan, Universitas Muhammadiyah Surakarta dan Bapak Ibu guru Mts Muhammadiyah 6 Bayat yang telah memberikan waktu dan tempat untuk melakukan penelitian di sekolah tersebut, serta adik-adik yang telah membantu mengisi angket yang diberikan. Tidak lupa mengucapkan terimakasih kepada orang tua dan dosen yang telah memberikan dukungan dan bimbingan.

\section{Daftar Rujukan}

Astuti Ati. (2015). Pelaksanaan Program Sekolah Siaga Bencana di SMA Negeri 1 Karanganom Klaten. Semarang: UNNES

Hidayati Deny. (2008). Kesiapsiagaan Masyarakat: Paradigma Baru Pengelolaan Bencana Alam di Indonesia. PPK-LIPI

Kristianti. (2013). Kesiapsiagaan Masyarakat Terhadap Bencana Gempa Bumi di Dusun Piring Desa Srihardono Kecamatan Pundong Kabupaten Bantul.Yogyakarta: UNY

Nuryanti. (2007). Gempa Bumi Seri Bencana Alam. Karya Putra Darwati Bandung

Sunarhadi Amin dkk. (2018). Model Pendidikan Kebencanaan di Klaten. Yogyakarta: LPB

Wahyuni Elida. (2011). "Tingkat Pengetahuan Siswa Tentang Kesiapsiagaan Bencana di SMAN 1 Pariaman Sumatra Barat dan SMAN 2 Depok Jawa Barat Tahun 2011”. Skripsi Fakultas Kesehatan Masyarakat Program Studi Ilmu Kesehatan Masyarakat Peminatan Kebidanan Komunitas Universitas Indonesia. 2011

Widjanarko Mochamad. (2018). Pengaruh Pendidikan Bencana Pada Perilaku Kesiapsiagaan Siswa. Kudus: Universitas Muria Kudus 